\title{
Konrad Bączek
}

\section{SPRAWOZDANIE Z KONFERENCJI BUDOWA NIEPODLEGEEJ. GRANICE RZECZYPOSPOLITEJ W LATACH 1918-1921}

Odzyskanie przez Polskę niepodległości po 123 latach niewoli było ściśle związane z rezultatami I wojny światowej. Poważne osłabienie, a w przypadku $\mathrm{Au}-$ stro-Węgier rozpad, mocarstw zaborczych, pozwoliło na intēnsyfikacje akcji politycznej i militarnej zmierzajaccej do odbudowy niepodległego państwa.Zasadniczy element procesu odrodzenia suwerennej Polski stanowiła walka o jej granice. $\mathrm{Po}$ lacy musieli zmierzyć się z roszczeniami dawnych zaborców oraz aspiracjami terytorialnymi sąsiednich narodów, które po I wojnie światowej uzyskały możliwość samostanowienia. O kształcie granic II RP zdecydowały w dużej mierze działania zbrojne tj. Powstanie Wielkopolskie (1918), powstania śląskie (1919-1921), wojna o Śląsk Cieszyński (1919), wojna polsko-sowiecka (1919-1921), czy wreszcie kontrowersyjny Bunt Żeligowskiego (1920). Jedynie w przypadku granicy północnej wystarczające (choć nie wszystkich satysfakcjonujące) okazały się rozstrzygnięcia dyplomatyczne. Na mocy ustaleń traktatu wersalskiego Polska uzyskała część dawnych Prus Królewskich z dostępem do morza, natomiast o przynależności państwowej Warmii, Mazur i Powiśla miał zdecydować wynik plebiscytu zorganizowanego 11 lipca $1920 \mathrm{r}$.

Kwestia kształtowania granic II RP cieszy się nieustającym zainteresowaniem historyków polskich, a także (może w nieco mniejszym stopniu) zagranicznych. Okazją do prezentacji wyników najnowszych badań oraz wymiany poglądów stała się konferencja naukowa zatytułowana: Budowa Niepodległej. Granice Rzeczypospolitej w latach 1918-1921 zorganizowana w dniach 10-11 października 2019 r. przez Instytut Północny im. Wojciecha Kętrzyńskiego w Olsztynie, Oddział Polskiej Akademii Nauk w Olsztynie i Białymstoku z siedzibą w Olsztynie oraz Regionalny Ośrodek Debaty Międzynarodowej w Olsztynie. Patronat Honorowy nad konferencją objęło Ministerstwo Kultury i Dziedzictwa Narodowego, zaś patronat medialny TVP 3 Olsztyn i Radio Olsztyn S.A. 
Konferencję poprzedziło otwarcie przez dyrektora Instytutu Północnego wystawy pt. Koniec I wojny światowej w satyrze i karykaturze. Ekspozycja została przygotowana przez dr. Tomasza Wyżlica z Instytutu Północnego w oparciu o materiały graficzne zamieszczone w czasopismach polskich („Mucha”, „Szczutek”, „Kocynder”) oraz niemieckich („Ulk”, „Kladderadatsch”, „Der Wahre Jacob”). Ekspozycja składa się z 28 plansz podzielonych na 4 bloki tematyczne, zatytułowane kolejno: „Po wojnie”, „Wersal”, „Plebiscyt” i „Stereotypy”. Kurator wystawy, dr Tomasz Wyżlic, przybliżył zgromadzonym tematykę ukazaną w ekspozycji, nierzadko przytaczając szereg mniej znanych informacji, dotyczących zarówno prezentowanych materiałów, jak i wydarzeń sprzed stu lat, mających niemały wpływ na relacje polsko-niemieckie.

$\mathrm{Na}$ planszach zostały zaprezentowane rysunki satyryczne oraz karykatury, wraz z objaśnieniami odnoszącymi się do wymienionych wyżej bloków tematycznych. O wartości wystawy stanowi nieznany dotąd szerzej, bogaty materiał ikonograficzny. Lekka, nieraz żartobliwa forma ekspozycji sprawia, że może ona być z powodzeniem adresowana do szerokiego grona odbiorców, jako przystępne źródło wiedzy na temat ważnego epizodu w dziejach Warmii, Mazur i Powiśla, a także Polski i Europy (wystawa była dostępna dla zwiedzających do końca 2019 r. w siedzibie Instytutu Północnego w Olsztynie, został również wydany jej katalog).

Następnie rozpoczęły się obrady konferencji. Pierwszego dnia zaprezentowane zostały cztery referaty: Kwestia granicy polsko-litewskiej w 1919 roku prof. dr. hab. Krzysztofa Buchowskiego (Uniwersytet w Białymstoku), Górny Ślask w Czechostowackim programie terytorialnym 1918-1923 dr. hab. Piotra Pałysa (Instytut Śląski w Opolu), Stosunki niemiecko-sowieckie w aspekcie Prus Wschodnich podczas wojny polsko-bolszewickiej na forum Sejmu Ustawodawczego 1919-1922 dr. hab. Zbigniewa Kudrzyckiego (Towarzystwo Naukowe im. Wojciecha Kętrzyńskiego w Olsztynie). Pierwszy dzień obrad zamknął referat dr hab. Haliny Łach (Uniwersytet Warmińsko-Mazurski) zatytułowany: Demarkacja polsko-rosyjskiej granicy państwowej (1922-1923).

Drugiego dnia referaty zostały wygłoszone w dwóch blokach. W pierwszym z nich zaprezentowano cztery wystąpienia: mgr Tadeusz Baryła (Instytut Północny w Olsztynie) Polska służba konsularna w Prusach Wschodnich po I wojnie światowej, dr Tomasz Wyżlic (Instytut Północny w Olsztynie) Granica Prus Wschodnich na odcinku $z$ Polskg w latach 1919-1923, dr hab. Wasyl Gulaj (Uniwersytet Narodowy Politechnika Lwowska) Problem kształtowania granic odbudowanego państwa polskiego w latach 1918-1923 we wspótczesnym ukraińskim dyskursie akademickim i społeczno-politycznym, dr Piotr Bojarski (Instytut Północny w Olsztynie) Walka o granice Rzeczypospolitej widziana oczami gen. Adriana Cartona de Wiarta - Szefa Brytyjskiej Misji Wojskowej w Warszawie. 
Po przerwie wygłoszono następujące referaty: dr Grzegorz Kała (Gdańsk) Walka o granice niepodległej w propagandzie Obozu Zjednoczenia Narodowego, dr Małgorzata Łapa (Uniwersytet Łódzki) Ochrona celna granic i zagraniczna wymiana towarowa Rzeczypospolitej w latach 1918-1921, dr Maciej Grabski (Instytut Północny w Olsztynie) Plebiscyt na Warmii, Mazurach i Powiślu i jego przebieg na łamach „Kuriera Poznańskiego”, dr Emilia Figura-Osełkowska (Instytut Północny w Olsztynie) Ruch turystyczny do Prus Wschodnich przez „korytarz pomorski”, mgr Waldemar Borzestowski (Uniwersytet Gdański) Ignacy Jan Paderewski w Gdańsku - grudzień 1918 r. Oczekiwania i rzeczywistość, mgr Kamil Szołdra (Uniwersytet Opolski) Śląskie echa powstania wielkopolskiego, mgr Romualda Piotrkiewicz (Archiwum Państwowe w Olsztynie) Granica w badaniach historycznych przy wykorzystaniu serwerów GIS.

Po zakończeniu drugiego bloku dyrektor Instytutu Północnego dokonał podsumowania konferencji i zamknięcia obrad. 